\title{
Effect of salinity on tomato (Lycopersicon esculentum Mill.) during seed germination stage
}

\author{
Jogendra Singh • E. V. Divakar Sastry • Vijayata Singh
}

Published online: 8 December 2011

(C) Prof. H.S. Srivastava Foundation for Science and Society 2011

\begin{abstract}
A study was conducted using ten genetically diverse genotypes along with their $45 \mathrm{~F}_{1}$ (generated by diallel mating) under normal and salt stress conditions. Although, tomato (Lycopersicon esculentum Mill.) is moderately sensitive to salinity but more attention to salinity is yet to be required in the production of tomato. In present study, germination rate, speed of germination, dry weight ratio and $\mathrm{Na}^{+} / \mathrm{K}^{+}$ratio in root and shoot, were the parameters assayed on three salinity levels; control, $1.0 \% \mathrm{NaCl}$ and $3.0 \% \mathrm{NaCl}$ with Hoagland's solution. Increasing salt stress negatively affected growth and development of tomato. When salt concentration increased, germination of tomato seed was reduced and the time needed to complete germination lengthened, root/shoot dry weight ratio was higher and $\mathrm{Na}^{+}$content increased but $\mathrm{K}^{+}$content decreased. Among the varieties, Sel-7 followed by Arka Vikas and crosses involving them as a parent were found to be the more tolerant genotypes in the present study on the basis of studied parameters.
\end{abstract}

Keywords Lycopersicon esculentum . Growth parameters . Salinity stress $\cdot$ Tomato $\cdot$ Effect of salinity

\footnotetext{
J. Singh $(\bowtie)$

Central Soil Salinity Research Institute,

Karnal, Haryana, India

e-mail: jogendra82@gmail.com

E. V. D. Sastry

Department of Plant Breeding and Genetics,

S.K.N. College of Agriculture,

Jobner, India

V. Singh

Department of Plant Breeding and Genetics, CCS HAU,

Hisar, India
}

\section{Introduction}

Salinity is currently one of the most severe abiotic factors, limiting agricultural production. In arid and semi arid lands, the plants are subjected throughout their life cycle to different stresses; some of these plants can tolerate these stresses in different ways depending upon plant species and type of stress. Excessive salinity reduces the productivity of many agricultural crops including most of the vegetables. Knowledge of salt tolerance in vegetable plants is necessary to increase productivity and profitability of crops irrigated with saline wastewaters. According to USDA report, out of all vegetables, tomato is moderately sensitive to salinity. Salt stress has three fold effects which reduces water potential and causes ion imbalance and toxicity (de la Peña and Hughes 2007). Salt stress affects some major processes such as germination, speed of germination, root/shoot dry weight and $\mathrm{Na}^{+} / \mathrm{K}^{+}$ratio in root and shoot (Parida and Das 2005). Salinity tolerance is critical during the life cycle of any species. Large genetic variation of tolerance to salt level exists among tomato genotypes. However, salt tolerance breeding programs have been restricted by the complexity of the trait, insufficient genetic and physiological knowledge of tolerance-related traits, and lack of efficient selection domain. Most commercial cultivars of tomato are sensitive to moderate levels of salinity up to $2.5 \mathrm{dSm}-{ }^{1}$, without significant yield reduction. Correcting saline condition in field and greenhouse would be expensive and temporary while selection and breeding for salt tolerance can be a wise solution to minimize salinity effects as well as improve production efficiency. So breeding tolerant cultivars of tomato under saline conditions is needed. Genetic characterization of useful germplasm is the first step toward releasing tolerant cultivars. This study tried to find any level of tolerance to saline conditions in 55 tomato genotypes. 
The objective of the present work was to investigate the response of tomato genotypes to increasing salinity during the germination and seedling stages. It has been shown that crops which are tolerant at seedling stage also show improved salinity tolerance at adult stage (Akinci et al. 2004).

\section{Materials and methods}

Ten genetically diverse tomato varieties were collected from Division of Vegetable Science, IARI, New Delhi, with varying degree of salt tolerance named IIVR-Sel-2, Arka Vikas, Sel-7, Azad T-2, Punjab Upma, DARL-64, BSS-368, Himsona, Tom-187 and CO-3. These varieties were crossed in all possible combinations excluding reciprocals to generate $45 \mathrm{~F}_{1} \mathrm{~s}$ during kharif, 2007 at S.K.N. college of Agriculture. All crosses along with parents were evaluated in laboratory in 2008-09 in completely randomized block design.

Seeds of all the genotypes (parents and $\mathrm{F}_{1} \mathrm{~s}$ ) were surface sterilized with $0.1 \%$ mercuric chloride solution for five minutes, then washed with sterilized distilled water. 25 seeds of each genotype were sown per Petri plate per salinity level. Salinity levels were created by supplementing the Hoagland solution with $\mathrm{NaCl}$; control (only Hoagland's solution), $1.0 \%$ and $3.0 \% \mathrm{NaCl}$ with ECe values of 0.18 , 2.5 , and $4.5 \mathrm{dSm}^{-1}$ respectively. Each Petri dish was layered with Whatman's No.1 filter paper and irrigated with $5 \mathrm{ml}$ of test solution after draining the previous day's solution. The Petri dishes were kept under artificial light $(9 \mathrm{hrs} /$ day $)$ at $20{ }^{\circ} \mathrm{C}$ in a culture room to complete the seedling growth. Whole set up was replicated twice. On the 14th day of the experiment, germination (\%), speed of germination (days), dry weight ratio of root and shoot and $\mathrm{Na}^{+} / \mathrm{K}^{+}$ratio in root and shoot was measured. $\mathrm{Na}^{+}$and $\mathrm{K}^{+}$concentration were determined by using atomic absorption spectrophotometer (Perkin Elmer 3110, United States). Significance of treatments was determined with the help of $F$-test.

\section{Results and discussion}

Three levels (control, $1.0 \% \mathrm{NaCl}$ and $3.0 \% \mathrm{NaCl}$ concentrations) of Hoagland's solution were used to evaluate the effect of salinity on different growth parameters of tomato genotypes.

\section{Effect of salinity on germination}

The germination of tomato seed was reduced at relatively low salinity $(1 \% \mathrm{NaCl})$. At higher salinity $(3 \% \mathrm{NaCl})$, the germination percentage declined drastically from $77.60 \%$ (control) to $29.60 \%$ (at $3 \% \mathrm{NaCl}$ ) in parents and from $75.82 \%$ (control) to $33.16 \%$ (at $3 \% \mathrm{NaCl}$ ) in $\mathrm{F}_{1}$ s. The establishment of competitive crop would be difficult in this salinity condition.

There were differences in the germination percentage between the parents and $F_{1}$ s particularly in salinity. As for the parents, germination percentage ranged from $60 \%$ to $90 \%$ (control), $20 \%$ to $80 \%$ (at $1 \% \mathrm{NaCl}$ ) and $4 \%$ to $52 \%$ (at $3 \% \mathrm{NaCl}$ ). Whereas, among $\mathrm{F}_{1} \mathrm{~s}$, the range was $20 \%$ to $96 \%$ (control), $4 \%$ to $80 \%$ (at $1 \% \mathrm{NaCl}$ ) and $4 \%$ to $64 \%$ (at $3 \% \mathrm{NaCl}$ ) (Table 1).

Among the parents, Sel- 7 and in F $_{1}$ s, Sel- 7 x BSS-368 were least affected by higher salinity stress. The genotypes which are least affected may be potential source of salinity tolerance for tomato breeding (Cuartero and Munoz 1999; Hazer et al. 2006; Amir et al. 2011; Hamed et al. 2011). The effect of external salinity on seed germination may be partially osmotic or ion toxicity, which can alter physiological processes such as enzyme activities (Croser et al. 2001; Essa and Al-Ani 2001).

\section{Effect of salinity on speed of germination}

The salinity notably affects germination in many species but also lengthens the time needed to complete germination (Amir et al. 2011). In the present study also the speed of germination was reduced i.e. it took more days to complete the germination under salinity. In parents, this ranged from 4.90 days (control) to 13.20 days (at $3 \% \mathrm{NaCl}$ ) and in $\mathrm{F}_{1} \mathrm{~s}$, from 5.11 days (control) to 13.36 days (at $3 \% \mathrm{NaCl}$ ) (Table 1). The earliest germinating parents and $\mathrm{F}_{1} \mathrm{~s}$ at higher salinity level were ArkaVikas, Sel-7 and Azad T-2; Azad T-2 x Himsona and Himsona x CO-3, respectively. Tomato seeds needed approximately $50 \%$ additional time to germinate at $1 \% \mathrm{NaCl}$ than in control medium and almost $100 \%$ more time at $3 \% \mathrm{NaCl}$ concentration (Table 1). Genotypes which germinate earlier at higher salinity are supposed to be more vigorous and may be used as parents or potential donor in salinity tolerance crop breeding programmes (Cuartero and Munoz 1999; Amir et al. 2011; Hamed et al. 2011). The stimulation of germination and days required for its completion, depend upon Gibbrelic Acid content in seed. A low level of GA in seed in saline medium was unable to break the mechanical resistance of endosperm against imbibition of water by seed and this leads to the reduction in speed of germination (Groot and Karssen 1992; Groot et al. 1988).

Effect of salinity on root/shoot dry weight ratio

In spite of the negative effects of salt on roots, the root growth in tomato appears to be less affected whereas, shoot was affected drastically, so that, the dry weight ratio was 
Table 1 Effect of salinity on the different traits of the tomato

\begin{tabular}{|c|c|c|c|c|c|c|c|c|c|}
\hline \multirow[t]{2}{*}{ Genotypes } & \multicolumn{3}{|c|}{ Germination (\%) } & \multicolumn{3}{|c|}{ Speed of germination (days) } & \multicolumn{3}{|c|}{ Root/Shoot dry weight ratio } \\
\hline & Control & $1 \% \mathrm{NaCl}$ & $3 \% \mathrm{NaCl}$ & Control & $1 \% \mathrm{NaCl}$ & $3 \% \mathrm{NaCl}$ & Control & $1 \% \mathrm{NaCl}$ & $3 \% \mathrm{NaCl}$ \\
\hline IIVR-Sel-2 & 76.00 & 52.00 & 36.00 & 5.00 & 7.00 & 13.00 & 0.571 & 0.588 & 0.629 \\
\hline Arka Vikas & 64.00 & 36.00 & 24.00 & 5.00 & 8.00 & 12.00 & 0.516 & 0.539 & 0.647 \\
\hline Sel.-7 & 96.00 & 80.00 & 52.00 & 4.00 & 7.00 & 12.00 & 0.765 & 0.793 & 0.875 \\
\hline Azad T-2 & 92.00 & 64.00 & 40.00 & 5.00 & 7.00 & 12.00 & 0.500 & 0.583 & 0.600 \\
\hline Punjab Upma & 60.00 & 48.00 & 40.00 & 5.00 & 10.00 & 13.00 & 0.555 & 0.684 & 0.786 \\
\hline DARL-64 & 76.00 & 28.00 & 4.00 & 5.00 & 9.00 & 14.00 & 0.531 & 0.560 & 0.647 \\
\hline BSS-368 & 60.00 & 20.00 & 16.00 & 5.00 & 10.00 & 14.00 & 0.500 & 0.524 & 0.563 \\
\hline Himsona & 80.00 & 64.00 & 44.00 & 5.00 & 11.00 & 14.00 & 0.457 & 0.475 & 0.516 \\
\hline Tom-187 & 80.00 & 52.00 & 20.00 & 5.00 & 7.00 & 14.00 & 0.449 & 0.500 & 0.567 \\
\hline $\mathrm{CO}-3$ & 92.00 & 48.00 & 20.00 & 5.00 & 9.00 & 14.00 & 0.417 & 0.429 & 0.580 \\
\hline Mean & 77.60 & 49.20 & 29.60 & 4.90 & 8.50 & 13.20 & 0.53 & 0.57 & 0.64 \\
\hline IIVR-Sel-2 x Arka Vikas & 44.00 & 36.00 & 24.00 & 5.00 & 9.00 & 12.00 & 0.389 & 0.429 & 0.526 \\
\hline IIVR-Sel-2 x Sel.-7 & 36.00 & 32.00 & 16.00 & 5.00 & 7.00 & 14.00 & 0.400 & 0.470 & 0.539 \\
\hline IIVR-Sel-2 x Azad T-2 & 84.00 & 72.00 & 60.00 & 5.00 & 6.00 & 13.00 & 0.436 & 0.477 & 0.563 \\
\hline IIVR-Sel-2 x Punjab Upma & 68.00 & 52.00 & 40.00 & 5.00 & 8.00 & 14.00 & 0.375 & 0.410 & 0.448 \\
\hline IIVR-Sel-2 x DARL-64 & 92.00 & 68.00 & 48.00 & 6.00 & 9.00 & 12.00 & 0.421 & 0.444 & 0.472 \\
\hline IIVR-Sel-2 x BSS-368 & 60.00 & 52.00 & 28.00 & 5.00 & 10.00 & 14.00 & 0.436 & 0.482 & 0.522 \\
\hline IIVR-Sel-2 x Himsona & 72.00 & 56.00 & 40.00 & 5.00 & 10.00 & 14.00 & 0.528 & 0.555 & 0.666 \\
\hline IIVR-Sel-2 x Tom-187 & 84.00 & 72.00 & 52.00 & 6.00 & 9.00 & 14.00 & 0.419 & 0.465 & 0.548 \\
\hline IIVR-Sel-2 x CO-3 & 72.00 & 32.00 & 20.00 & 5.00 & 8.00 & 14.00 & 0.594 & 0.666 & 0.736 \\
\hline Arka Vikas x Sel.-7 & 72.00 & 60.00 & 32.00 & 5.00 & 6.00 & 14.00 & 0.298 & 0.306 & 0.324 \\
\hline Arka Vikas x Azad T-2 & 84.00 & 68.00 & 56.00 & 5.00 & 6.00 & 14.00 & 0.489 & 0.500 & 0.606 \\
\hline Arka Vikas x Punjab Upma & 88.00 & 72.00 & 60.00 & 5.00 & 9.00 & 14.00 & 0.412 & 0.450 & 0.533 \\
\hline Arka Vikas x DARL-64 & 44.00 & 32.00 & 28.00 & 7.00 & 11.00 & 14.00 & 0.542 & 0.556 & 0.615 \\
\hline Arka Vikas x BSS-368 & 64.00 & 20.00 & 12.00 & 5.00 & 10.00 & 14.00 & 0.472 & 0.577 & 0.632 \\
\hline Arka Vikas x Himsona & 72.00 & 20.00 & 12.00 & 5.00 & 11.00 & 14.00 & 0.409 & 0.444 & 0.482 \\
\hline Arka Vikas x Tom-187 & 20.00 & 4.00 & 4.00 & 7.00 & 12.00 & 14.00 & 0.474 & 0.500 & 0.571 \\
\hline Arka Vikas x CO-3 & 76.00 & 20.00 & 20.00 & 5.00 & 8.00 & 14.00 & 0.465 & 0.563 & 0.652 \\
\hline Sel.-7 x Azad T-2 & 80.00 & 68.00 & 40.00 & 6.00 & 11.00 & 13.00 & 0.407 & 0.435 & 0.486 \\
\hline Sel.-7 x Punjab Upma & 84.00 & 68.00 & 52.00 & 5.00 & 8.00 & 13.00 & 0.526 & 0.566 & 0.652 \\
\hline Sel.-7 x DARL-64 & 88.00 & 40.00 & 16.00 & 5.00 & 10.00 & 14.00 & 0.447 & 0.475 & 0.552 \\
\hline Sel.-7 x BSS-368 & 92.00 & 76.00 & 64.00 & 4.00 & 9.00 & 13.00 & 0.453 & 0.489 & 0.514 \\
\hline Sel.-7 x Himsona & 64.00 & 32.00 & 20.00 & 5.00 & 9.00 & 14.00 & 0.486 & 0.536 & 0.760 \\
\hline Sel.-7 x Tom-187 & 88.00 & 60.00 & 28.00 & 5.00 & 10.00 & 13.00 & 0.511 & 0.553 & 0.621 \\
\hline Sel.-7 x CO-3 & 84.00 & 48.00 & 20.00 & 5.00 & 9.00 & 13.00 & 0.511 & 0.541 & 0.615 \\
\hline Azad T-2 x Punjab Upma & 84.00 & 60.00 & 32.00 & 5.00 & 9.00 & 14.00 & 0.468 & 0.528 & 0.680 \\
\hline Azad T-2 x DARL-64 & 92.00 & 60.00 & 20.00 & 4.00 & 7.00 & 13.00 & 0.439 & 0.548 & 0.645 \\
\hline Azad T-2 x BSS-368 & 96.00 & 72.00 & 48.00 & 4.00 & 6.00 & 12.00 & 0.422 & 0.471 & 0.513 \\
\hline Azad T-2 x Himsona & 96.00 & 80.00 & 60.00 & 4.00 & 7.00 & 11.00 & 0.433 & 0.500 & 0.548 \\
\hline Azad T-2 x Tom-187 & 76.00 & 48.00 & 36.00 & 5.00 & 10.00 & 14.00 & 0.525 & 0.594 & 0.727 \\
\hline Azad T-2 x CO-3 & 80.00 & 64.00 & 28.00 & 5.00 & 8.00 & 14.00 & 0.550 & 0.625 & 0.739 \\
\hline Punjab Upma x DARL-64 & 68.00 & 60.00 & 32.00 & 6.00 & 10.00 & 14.00 & 0.581 & 0.652 & 0.722 \\
\hline Punjab Upma x BSS-368 & 76.00 & 48.00 & 24.00 & 5.00 & 9.00 & 13.00 & 0.594 & 0.654 & 0.737 \\
\hline Punjab Upma x Himsona & 80.00 & 60.00 & 40.00 & 5.00 & 11.00 & 14.00 & 0.568 & 0.600 & 0.625 \\
\hline Punjab Upma x Tom-187 & 84.00 & 60.00 & 48.00 & 5.00 & 7.00 & 13.00 & 0.434 & 0.475 & 0.516 \\
\hline Punjab Upma x CO-3 & 64.00 & 40.00 & 28.00 & 6.00 & 10.00 & 14.00 & 0.516 & 0.565 & 0.667 \\
\hline DARL-64 x BSS-368 & 80.00 & 60.00 & 40.00 & 5.00 & 9.00 & 13.00 & 0.537 & 0.567 & 0.650 \\
\hline
\end{tabular}


Table 1 (continued)

\begin{tabular}{|c|c|c|c|c|c|c|c|c|c|}
\hline \multirow[t]{2}{*}{ Genotypes } & \multicolumn{3}{|c|}{ Germination (\%) } & \multicolumn{3}{|c|}{ Speed of germination (days) } & \multicolumn{3}{|c|}{ Root/Shoot dry weight ratio } \\
\hline & Control & $1 \% \mathrm{NaCl}$ & $3 \% \mathrm{NaCl}$ & Control & $1 \% \mathrm{NaCl}$ & $3 \% \mathrm{NaCl}$ & Control & $1 \% \mathrm{NaCl}$ & $3 \% \mathrm{NaCl}$ \\
\hline DARL-64 x Himsona & 64.00 & 16.00 & 4.00 & 6.00 & 11.00 & 14.00 & 0.533 & 0.546 & 0.667 \\
\hline DARL-64 x Tom-187 & 84.00 & 68.00 & 32.00 & 5.00 & 7.00 & 13.00 & 0.512 & 0.586 & 0.652 \\
\hline DARL-64 x CO-3 & 92.00 & 72.00 & 36.00 & 4.00 & 10.00 & 12.00 & 0.521 & 0.553 & 0.616 \\
\hline BSS-368 x Himsona & 68.00 & 28.00 & 20.00 & 5.00 & 9.00 & 14.00 & 0.515 & 0.538 & 0.611 \\
\hline BSS-368 x Tom-187 & 76.00 & 48.00 & 24.00 & 6.00 & 11.00 & 13.00 & 0.465 & 0.500 & 0.546 \\
\hline BSS-368 x CO-3 & 64.00 & 28.00 & 16.00 & 6.00 & 10.00 & 14.00 & 0.548 & 0.611 & 0.643 \\
\hline Himsona x Tom-187 & 88.00 & 68.00 & 52.00 & 5.00 & 8.00 & 13.00 & 0.522 & 0.539 & 0.600 \\
\hline Himsona x CO-3 & 96.00 & 76.00 & 60.00 & 4.00 & 7.00 & 11.00 & 0.529 & 0.550 & 0.571 \\
\hline Tom-187 x CO-3 & 92.00 & 60.00 & 20.00 & 4.00 & 6.00 & 12.00 & 0.500 & 0.527 & 0.600 \\
\hline Mean & 75.82 & 51.91 & 33.16 & 5.11 & 8.82 & 13.36 & 0.48 & 0.52 & 0.60 \\
\hline $\mathrm{SD}$ mean $(\sigma \mathrm{m})$ & 24.45 & & & 3.55 & & & 0.095 & & \\
\hline SEm & 0.81 & & & 0.83 & & & 0.06 & & \\
\hline $\mathrm{CD}(P=0.05)$ & 2.26 & & & 2.31 & & & 0.17 & & \\
\hline
\end{tabular}

Table 2 Effect of salinity on the different traits of the tomato

\begin{tabular}{|c|c|c|c|c|c|c|}
\hline \multirow[t]{2}{*}{ Genotypes } & \multicolumn{3}{|c|}{$\mathrm{Na}^{+} / \mathrm{K}^{+}$ratio in root } & \multicolumn{3}{|c|}{$\mathrm{Na}^{+} / \mathrm{K}^{+}$ratio in shoot } \\
\hline & Control & $1 \% \mathrm{NaCl}$ & $3 \% \mathrm{NaCl}$ & Control & $1 \% \mathrm{NaCl}$ & $3 \% \mathrm{NaCl}$ \\
\hline IIVR-Sel-2 & 2.52 & 3.22 & 2.02 & 1.78 & 1.92 & 1.89 \\
\hline Arka Vikas & 1.01 & 3.37 & 1.61 & 0.75 & 4.32 & 2.80 \\
\hline Sel.-7 & 1.62 & 2.25 & 2.08 & 1.50 & 2.28 & 2.72 \\
\hline Azad T-2 & 2.28 & 2.38 & 2.28 & 3.19 & 2.15 & 4.47 \\
\hline Punjab Upma & 2.15 & 4.40 & 2.63 & 2.73 & 2.94 & 3.46 \\
\hline DARL-64 & 2.55 & 2.42 & 2.53 & 3.85 & 4.57 & 5.04 \\
\hline BSS-368 & 3.12 & 2.49 & 2.47 & 3.14 & 1.74 & 2.00 \\
\hline Himsona & 3.32 & 2.80 & 3.65 & 2.04 & 2.78 & 2.68 \\
\hline Tom-187 & 2.46 & 3.52 & 7.22 & 3.28 & 3.97 & 5.18 \\
\hline $\mathrm{CO}-3$ & 3.38 & 3.47 & 3.36 & 2.54 & 3.20 & 3.10 \\
\hline Mean & 2.44 & 3.03 & 2.99 & 2.48 & 2.99 & 3.33 \\
\hline IIVR-Sel-2 x Arka Vikas & 2.38 & 3.24 & 4.90 & 1.96 & 3.11 & 5.54 \\
\hline IIVR-Sel-2 x Sel.-7 & 2.42 & 3.77 & 5.64 & 0.67 & 3.15 & 2.15 \\
\hline IIVR-Sel-2 x Azad T-2 & 1.71 & 1.81 & 2.24 & 2.24 & 3.29 & 7.99 \\
\hline IIVR-Sel-2 x Punjab Upma & 3.73 & 2.92 & 2.21 & 4.94 & 3.49 & 1.81 \\
\hline IIVR-Sel-2 x DARL-64 & 3.31 & 2.97 & 7.28 & 0.22 & 2.12 & 7.22 \\
\hline IIVR-Sel-2 x BSS-368 & 2.89 & 2.91 & 4.02 & 1.58 & 1.99 & 2.94 \\
\hline IIVR-Sel-2 x Himsona & 3.61 & 2.07 & 2.85 & 4.01 & 4.40 & 8.81 \\
\hline IIVR-Sel-2 x Tom-187 & 2.64 & 3.98 & 4.03 & 1.38 & 5.45 & 2.42 \\
\hline IIVR-Sel-2 x CO-3 & 1.43 & 4.48 & 6.67 & 0.73 & 0.96 & 4.19 \\
\hline Arka Vikas x Sel.-7 & 2.58 & 3.56 & 8.60 & 2.03 & 1.63 & 7.00 \\
\hline Arka Vikas x Azad T-2 & 4.23 & 3.98 & 11.00 & 0.37 & 1.06 & 4.50 \\
\hline Arka Vikas x Punjab Upma & 2.97 & 5.40 & 2.96 & 1.05 & 3.36 & 5.69 \\
\hline Arka Vikas x DARL-64 & 2.43 & 9.28 & 7.80 & 3.44 & 8.52 & 5.61 \\
\hline Arka Vikas x BSS-368 & 2.57 & 5.71 & 7.79 & 2.60 & 4.82 & 2.81 \\
\hline Arka Vikas x Himsona & 2.76 & 6.85 & 7.90 & 2.22 & 7.97 & 3.70 \\
\hline Arka Vikas x Tom-187 & 3.46 & 10.20 & 3.52 & 2.41 & 6.02 & 2.23 \\
\hline
\end{tabular}


Table 2 (continued)

\begin{tabular}{|c|c|c|c|c|c|c|}
\hline \multirow[t]{2}{*}{ Genotypes } & \multicolumn{3}{|c|}{$\mathrm{Na}^{+} / \mathrm{K}^{+}$ratio in root } & \multicolumn{3}{|c|}{$\mathrm{Na}^{+} / \mathrm{K}^{+}$ratio in shoot } \\
\hline & Control & $1 \% \mathrm{NaCl}$ & $3 \% \mathrm{NaCl}$ & Control & $1 \% \mathrm{NaCl}$ & $3 \% \mathrm{NaCl}$ \\
\hline Arka Vikas x CO-3 & 2.88 & 3.36 & 4.82 & 2.05 & 3.82 & 6.10 \\
\hline Sel.-7 x Azad T-2 & 2.08 & 4.04 & 3.10 & 3.31 & 2.83 & 3.35 \\
\hline Sel.-7 x Punjab Upma & 2.90 & 3.43 & 2.82 & 2.00 & 2.97 & 3.98 \\
\hline Sel.-7 x DARL-64 & 2.78 & 3.39 & 2.67 & 1.31 & 3.70 & 4.11 \\
\hline Sel.-7 x BSS-368 & 3.37 & 3.44 & 3.13 & 2.13 & 2.90 & 2.63 \\
\hline Sel-7 x Himsona & 4.21 & 3.19 & 2.80 & 3.07 & 2.66 & 2.52 \\
\hline Sel-7 x Tom-187 & 3.31 & 3.57 & 3.07 & 1.93 & 2.19 & 1.97 \\
\hline Sel.-7 x CO-3 & 3.58 & 3.02 & 2.82 & 2.84 & 3.01 & 2.48 \\
\hline Azad T-2 x Punjab Upma & 2.41 & 2.19 & 2.12 & 1.82 & 1.45 & 1.79 \\
\hline Azad T-2 x DARL-64 & 3.68 & 1.84 & 1.62 & 1.50 & 1.78 & 1.58 \\
\hline Azad T-2 x BSS-368 & 2.36 & 2.31 & 2.46 & 1.79 & 2.18 & 2.20 \\
\hline Azad T-2 x Himsona & 3.23 & 3.29 & 2.61 & 2.25 & 2.42 & 2.49 \\
\hline Azad T-2 x Tom-187 & 2.96 & 2.80 & 2.22 & 1.97 & 3.06 & 2.07 \\
\hline Azad T-2 x CO-3 & 2.55 & 2.15 & 2.06 & 2.21 & 1.95 & 2.03 \\
\hline Punjab Upma x DARL-64 & 3.89 & 2.26 & 2.25 & 2.54 & 2.27 & 2.37 \\
\hline Punjab Upma x BSS-368 & 5.86 & 4.30 & 8.74 & 4.62 & 5.99 & 3.43 \\
\hline Punjab Upma x Himsona & 5.63 & 3.38 & 4.39 & 2.79 & 1.81 & 1.87 \\
\hline Punjab Upma x Tom-187 & 3.60 & 3.13 & 2.40 & 1.88 & 1.90 & 1.95 \\
\hline Punjab Upma x CO-3 & 6.34 & 4.62 & 4.17 & 2.52 & 2.97 & 2.41 \\
\hline DARL-64 x BSS-368 & 1.71 & 1.64 & 1.52 & 4.21 & 1.79 & 1.67 \\
\hline DARL-64 x Himsona & 3.07 & 3.00 & 2.71 & 2.14 & 2.45 & 2.72 \\
\hline DARL-64 x Tom-187 & 3.03 & 2.63 & 2.34 & 4.56 & 4.67 & 3.12 \\
\hline DARL-64 x CO-3 & 3.66 & 2.82 & 3.70 & 2.70 & 2.75 & 2.24 \\
\hline BSS-368 x Himsona & 3.25 & 3.18 & 2.97 & 2.33 & 2.42 & 2.16 \\
\hline BSS-368 x Tom-187 & 3.16 & 2.84 & 3.01 & 2.65 & 2.97 & 2.58 \\
\hline BSS-368 x CO-3 & 2.92 & 2.80 & 2.78 & 1.91 & 2.35 & 2.10 \\
\hline Himsona x Tom-187 & 2.39 & 3.35 & 3.17 & 1.42 & 2.85 & 2.59 \\
\hline Himsona x CO-3 & 3.35 & 3.13 & 3.19 & 2.64 & 3.06 & 2.59 \\
\hline Tom-187 x CO-3 & 3.77 & 4.75 & 3.51 & 2.02 & 3.65 & 2.12 \\
\hline Mean & 3.18 & 3.62 & 3.97 & 2.29 & 3.16 & 3.33 \\
\hline SD Mean $(\sigma m)$ & 1.65 & & & 1.50 & & \\
\hline SEm & 1.48 & & & 0.39 & & \\
\hline $\mathrm{CD}(P=0.05)$ & 4.12 & & & 1.09 & & \\
\hline
\end{tabular}

higher in plant grown under salt stress than in control environment. In the present study, the root/shoot dry weight ratio was increased from 0.53 (control) to 0.64 (at $3 \%$ $\mathrm{NaCl}$ ) in parents and from 0.48 (control) to 0.64 (at $3 \%$ $\mathrm{NaCl}$ ) in $\mathrm{F}_{1} \mathrm{~s}$. The highest root/shoot dry weight ratio was observed at higher salinity for parent, Sel-7 and in $\mathrm{F}_{1} \mathrm{~s}$, for Sel-7 x Himsona (Table 1). The rise in root/shoot dry weight in tomato under salt stress must be accompanied by changes in the allocation of assimilates between root and shoot i.e. greater proportion of assimilates for root compared with shoot (Maggio et al. 2007; Amir et al. 2011; Hamed et al. 2011; Chookhampaeng et al. 2007).
Effect of salinity on $\mathrm{Na}^{+} / \mathrm{K}^{+}$ratio in root and shoot

A higher $\mathrm{Na}^{+}$concentration in root or shoot increases the osmotic potential and decreases water uptake, while $\mathrm{K}^{+}$ concentration in root or shoot of tomato plants, changes little under saline environment. Thus, increased concentration of $\mathrm{K}^{+}$in plant is consequently advisable in the present study for further breeding programme that is based on salinity tolerance. The mean values of $\mathrm{Na}^{+} / \mathrm{K}^{+}$ratio in root, varied from 2.44 (control) to 2.99 (at $3 \% \mathrm{NaCl}$ ) in parents and from 3.18 (control) to 3.97 (at $3 \% \mathrm{NaCl}$ ) in $\mathrm{F}_{1} \mathrm{~s}$ (Table 2). 
Whereas, in shoot, the mean value of $\mathrm{Na}^{+} / \mathrm{K}^{+}$ratio raised from 2.48 (control) to 3.33 (at $3 \% \mathrm{NaCl}$ ) in parents and from 2.29 (control) to 3.33 (at $3 \% \mathrm{NaCl}$ ) in $\mathrm{F}_{1}$ s (Table 2).

The lower value of $\mathrm{Na}^{+} / \mathrm{K}^{+}$ratio, indicated more uptake of $\mathrm{K}^{+}$from soil/medium by plants and such types of plants are similar to non-salinized plant i.e. salt tolerant. The desirable parents and $\mathrm{F}_{1} \mathrm{~s}$ having the lowest $\mathrm{Na}^{+} / \mathrm{K}^{+}$ratio in root, at high salinity level, were ArkaVikas and DARL-64 x BSS-368, respectively. Whereas, in shoot, lowest $\mathrm{Na}^{+} / \mathrm{K}^{+}$ ratio was observed for parent IIVR-Sel-2 and cross Azad T-2 x DARL-64. The genotypes which have low $\mathrm{Na}^{+} / \mathrm{K}^{+}$ ratio may be used in further breeding for salinity tolerance in tomato (Cuartero and Munzo 1999; Dasgan et al. 2002).

\section{Conclusions}

In the present study, Sel-7 followed by Arka Vikas and crosses involving them as a parent were found to be more tolerant genotypes among all the varieties on the basis of parameters studied. Tomato breeding should also resort to pyramiding the characteristics since no described traits alone is likely to produce a tolerant genotype. Threshold limit of salinity for tomato, up to which yield reduces very little or no reduction occur, is $2.5-3.0 \mathrm{dSm}^{-1}$ and after it, every increase of $1.0 \mathrm{dSm}^{-1}$ in ECe results in a yield reduction of about $9-10 \%$. The upper limit of salinity for tomato crop improvement is $6.0 \mathrm{dSm}^{-1}$. Beyond this, breeding programmes are not feasible because yield loss surpasses $50 \%$.

Acknowledgements I sincerely acknowledge to Dr. A. S. Sidhu, former Head Division of Horticulture and Vegetable Science, IARI, New Delhi and now Director of IIHR, Banglore, for his magnificent guidance, marvelous support and providing Tomato genotypes for my $\mathrm{Ph} . \mathrm{D}$. research.

\section{References}

Akinci IE, Akinci S, Dikici YHK (2004) Response of eggplant varieties (Solanum melongena) to salinity in germination and seedling stages. New Zealand J Crop Hort Sci 32:193-200

Amir N, Muhammad A, Muhammad AP, Irfan A (2011) Effect of halopriming on germination and seedling vigor of tomato. Afr J Agr Res 6(15):3551-3559

Chookhampaeng S, Pattanagul W, Theerakulpist P (2007) Screening some tomato commercial cultivars from Thailand for salinity. Asian J Plant Sci 6(5):788-794

Croser C, Renault S, Franklin J, Zwiazk J (2001) The effect of salinity on the emergence and seedling growth of picea mariana, Picea Glanca and Pinus barksiana. Environ Pollut 115:6-16

Cuartero J, Munoz RF (1999) Tomato and salinity. Scientia Horticulture 78:83-125

Dasgan HY, Aktas H, Abak K, Cakmar I (2002) Determination of screening techniques to salinity tolerance in tomatoes and investigation and investigation of genotypes response. Plant Sci 163 (4):695-703

de la Peña R, Hughes J (2007) Improving vegetable productivity in a variable and changing climate. SAT eJournal (ejournalicrisatorg) 4 (1): $1-22$

Essa AT, Al-Ani DH (2001) Effect of salt stress on the performance of six soybean genotypes. Pak J Biol Sci 4:175-177

Groot SPC, Karssen CM (1992) Dormancy and germination of abcissic acid deficient tomato seeds. Plant Physiol 99:952-958

Groot SPC, Kieliszewska-Rokicka B, Vermeer E, Karssen CM (1988) Giberellin induced hybrolysis of endosperm cell walls in giberellin deficient tomato seeds prior to radicle protrusion. Planta 174:500-504

Hamed K, Hossein N, Mohammad F, Safieh VJ (2011) How salinity affect germination and emergence of tomato lines. J Biol EnvironSci 5(15):159-163

Hazer AS, Malibari AA, Al-Zahrani HS, Al-Maghrabi OA (2006) Response of three tomato cultivars to sea water salinity. 1. Effect of salinity on the seedling growth. Afr J Biotechnol 5(10):855861

Maggio A, Raimondi G, Martinoi A, De-Parcale S (2007) Salt stress response in tomato beyond the salinity tolerance threshold. Environ Exp Bot 59(3):276-281

Parida AK, Das AB (2005) Salt tolerance and salinity effects on plant: a review. Ecotoxical Environ Safety 60:324-349 